\title{
SIMULATION OF PUBLIC PROCUREMENT'S IMPACT ON INNOVATIVENESS OF EU COUNTRIES
}

\author{
Markovic-Hribernik, T.* \& Detelj, K.* \\ * University of Maribor, Faculty of Economics and Business, Razlagova 14, 2000 Maribor, Slovenia \\ ${ }^{* *}$ University of Zagreb, Faculty of organization and informatics, Pavlinska 2, 42000 Varazdin, Croatia \\ E-mail: tanja.markovic@um.si, kristina.detelj@foi.hr
}

\begin{abstract}
Recently a lot of research has been devoted to studying the impact that public procurement can have on innovation. The phenomenon has been widely recognized as the effect of public procurement for (of) innovation (PPI). The purpose of this paper is to further explore the previous results of the econometric panel analysis by employing simulation modelling to check the robustness of the results and to add firmer arguments for evidence-based innovation policies.

The main results for the $28 \mathrm{EU}$ countries show that PPI and economic (GDP) growth are significant factors that affect the level of a country's innovativeness. By applying simulation models, the possible size of the impact in terms of changing the size of PPI on a country's level of innovativeness, can be seen. These results can have practical implications for officials in charge of innovation policies, because the recent crisis has stretched their budgets, meaning that they have to choose policy instruments that will have a significant impact.

(Received in June 2015, accepted in December 2015. This paper was with the authors 3 months for 1 revision.)
\end{abstract}

Key Words: Public Procurement, Innovation Policy Instruments, Innovativeness, Panel Analysis, Simulation

\section{INTRODUCTION}

The innovation policy in European Union has put a strong focus on the innovation potential of public procurement, especially after the beginning of the $21^{\text {st }}$ century (e.g. [1-4]). The main problem we want to put in focus is to find a way for the state to achieve greater effects in promoting innovation. State has different policy instrument at disposal, but recently the researchers have prompted a significant increase in the body of research on public procurement and its effect on innovation, in literature known as public procurement for (of) innovation - PPI (see the thorough review in [5]). However, the majority of this research is conducted at a micro level, i. e. they inquire into how the PPI affects the innovative activities and/or innovative results of the companies. Research at the micro level confirmed that the companies have better innovative results when these have been induced by PPI, or by a combination of a PPI and collaboration with others to create innovation [6, 7]. Moreover, the research still overwhelmingly relies on the qualitative analysis of case studies and not on the quantitative methods that include larger samples. Additionally, the research is mainly based on evidence from more developed countries (USA, UK, Germany, the Netherlands, Nordic countries etc.), while less developed countries (as well as transition countries from Central and Eastern Europe) are underrepresented in this field of research and the evidence is scarce. Regarding this, the authors have recently developed a macro model to test the PPI impact on a country's level of innovativeness where it is confirmed that the PPI is a significant factor among the incentives for innovation at the state level in the EU.[8].

This paper will go one step further and simulate models of the PPI's impact based on the results of a panel analysis on 28 EU countries. A panel analysis offered single regression coefficient for each variable in the model, whereas with simulation we can monitor the entire space of possible outcomes with different combinations of explanatory variables. Simulation 
modelling constitutes an interesting tool in many of the economic and other disciplines (operational production and supply chain management [9], project management [10], macroeconomics [11], environmental issues [12], etc.), but is also interesting for testing the possible effects of economic and other policies. An analysis of real life models by mathematical models or by experimental methods can be hard and unrealistic due to the complexity of phenomena and simplicity of the model [13]. When the researchers add more details into the model, it can make finding an analytic solution impossible [14]. This is where simulation modelling can offer new possibilities for researchers. If this provides new insights into the possible outcomes of their policies, this can be valuable for policy makers as well. As Brenner and Werker claim [15], the outcomes of policy measures are uncertain and might not reach policy goals, so policymakers today look for advice from experts who perform research in their policy area. They suggest that simulation modelling results can be used as arguments for evidence-based policies. Accepting advice from experts, however, cannot ensure that the policy will perform without error. These authors also point out that many problems in the process of building models stem from the way that researchers collect data. In the process of data collection, theories about real world phenomena are put into practice and the scientists try to observe and measure some representative aspects of the chosen phenomenon.

In the next chapter the authors will present the econometric model for the analysis of the impact of four innovation policy measures and show the results of the panel analysis of different model variations (baseline model, extended models, results of the time lagged explanatory variables and logarithmic transformation). This becomes the reasoning for the choice of the variables for the simulation model. They then develop simulation models for the analysis of the impact of the significant explanatory variables on the level of the innovativeness of the country that is in the focus of innovation policy. The article then provides a short analysis of the simulation modelling results, its limitations and some conclusions.

\section{PUBLIC PROCUREMENT FOR INNOVATION IN THE EU}

Countries in this globalised world want to create the conditions that help them achieve a satisfactory level of economic growth and international competitiveness to ensure their citizens good living standard. The EU thus devotes a lot of resources and activities to the promotion of innovation, which is an important factor for competitiveness. On the one side innovation has widely been researched from the micro perspective of a firm and the impact of innovation management on creation of new products and services [16-18]. On the other side the increasing body of research emerges, that deals with innovation policies, especially in the transition countries [19-21]. The role of the government in promoting innovation is very important because it mitigates risks for the subjects involved in innovation activities. Fig. 1 shows the described process, with the emphasis on the selection of widely spread innovation policy measures based on the Aschhoff and Sofka's work [6].

A large proportion of total government spending in the EU is accounted for by public procurement - around $16 \%$ of gross domestic product (GDP) [22], so public demand can also be a strong pull factor for innovation. The field of using the public procurement system in promoting the creation and diffusion of innovation thus comes into focus of many politicians, but also of the researchers. But in times of crisis, national budgets face restrictions. In this situation, growing deficits make it harder to direct sufficient funds to achieve the objectives of economic policies, including innovation policy. This is why policy must find the most effective ways of using the money at its disposal. 


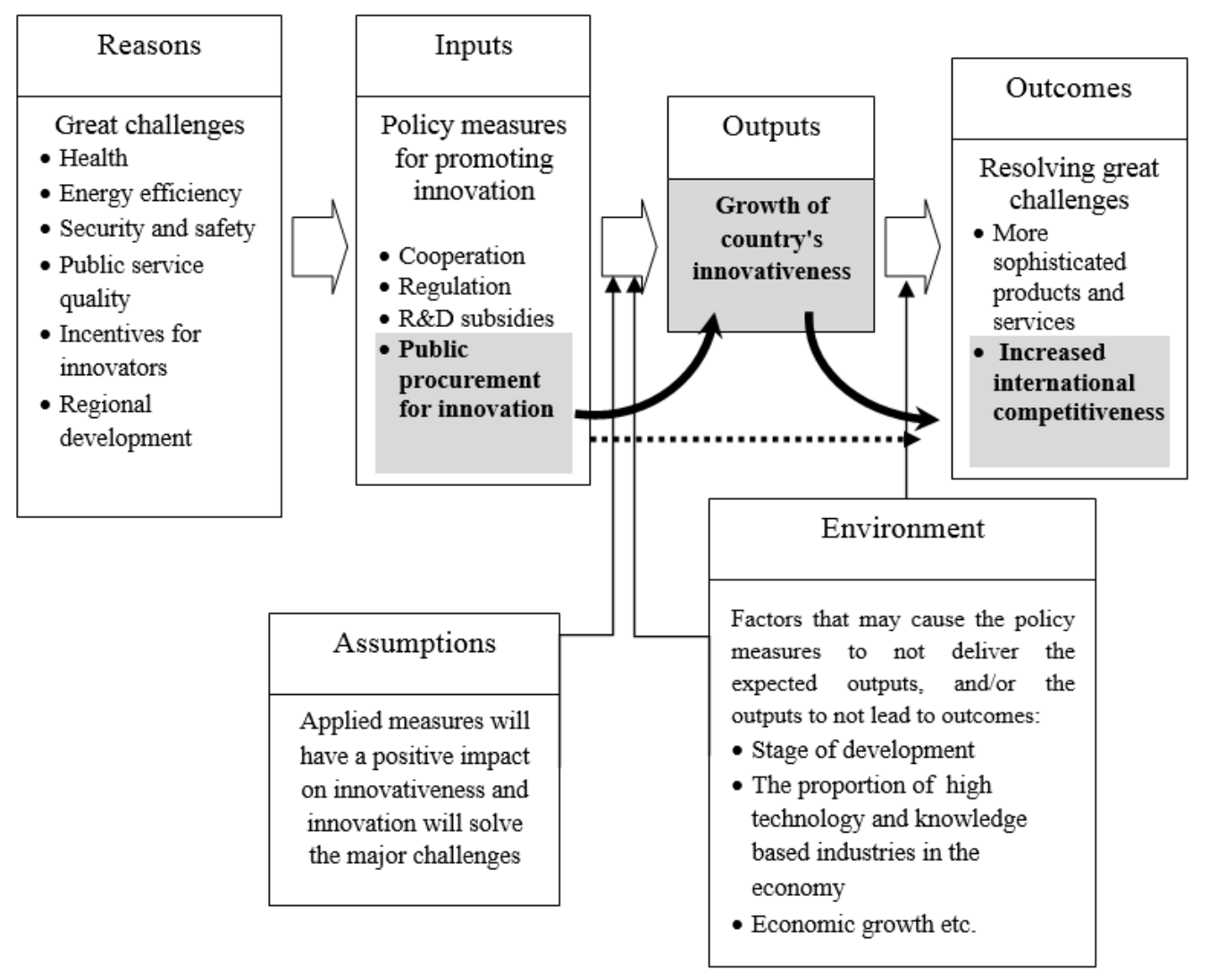

Figure 1: The logic model of possible channels for promoting innovation, adapted from [5].

\subsection{Econometric models for a panel analysis}

Based on these notions, and previous research, the authors have built a macro-level (country level) econometric model [8] that enables an analysis of different policy instruments on the level of the innovativeness of the EU countries. The model used panel data for $28 \mathrm{EU}$ countries to analyse the effects of the four policy measures on the innovativeness level of a country. When choosing the four policy measures, the authors used the theoretical basis from micro-level research (i.e. the level of enterprises in Germany) conducted by Aschhoff and Sofka [6]. Since the data for this research on a macro-level was not available for a longer time series, and not so many subjects have harmonized the data available, the analysis comprised data for 28 countries with an average timespan of 5.5 years. The panel analysis can combine two dimensions (time and cross-sectional dimensions) in the data and thus improve their usage since it provides more degrees of freedom and better efficiency and reliability of the estimators [23]. The nature of the researched phenomenon suggests that it would be useful to do the dynamic panel analysis, because the dependent variable could also be affected by its own previous values (such as in [24]), but it was not possible to estimate the dynamic panel models due to the short time series and only about 150 observations in static models.

As the dependent variable in the model, we used the indicator of business sophistication and innovation $(B S \& I)$ from competitiveness research by the World Economic Forum [25]. The $B S \& I$ includes a business sophistication pillar (the knowledge, skills and working conditions embedded in the organizations) and the technological innovation pillar (innovation as new products, services and processes) [26]. The index ranges from 1 to 7, with 7 representing the best result.

The basic regression model is as follows:

$$
B S \& I_{i t}=\beta_{1}+\beta_{2} \operatorname{COOP}_{i t}+\beta_{3} R Q_{i t}+\beta_{4} G B E R D_{i t}+\beta_{5} P P I_{i t}+u_{i t}
$$


The explanatory variables in our focus are the four policy measures through which the state supports the creation and/or diffusion of innovation:

- COOP - the proportion of firms that cooperate with others in the process of creating innovation,

- $R Q$ - regulatory quality,

- GBERD - share of Gross Business Expenditures for R\&D financed by the public sector (subsidies),

- $P P I-$ a measure of public procurement for innovation.

The basic model includes Cooperation with others in the creation of innovation (COOP) used Eurostat data [27], based on the Community Innovation Survey (CIS). COOP shows the share of enterprises in a country that cooperated with others (customers, suppliers, competitors, research institutes, universities, etc.) in the process of creating their innovations. The Regulatory Quality $(R Q)$ was measured by an indicator from Worldwide Governance Indicators (WGI), that shows the perception of a government's ability to create policies that promote the development of private companies [28]. The indicator reflects changes in business conditions due to changes in the regulatory framework. The indicator shows that the share of Gross Business R\&D Expenditures financed by the public sector $(G B E R D)$ is a quotient of the amount of euros spent on total Business Enterprise R\&D Expenditure $(B E R D)$ from public funds. For most of the 28 countries, the data was available for all of the years in the period from 2004 to 2011.

But the appropriate indicator for monitoring PPI is not readily available in official statistics. The EU prescribes regulatory thresholds above which the public entities are obliged to implement a mandatory procurement process [29]. But, there is no coordination in collecting data about performed procurement above the thresholds, let alone below them [30]. In the published literature to date, only the estimates of the total Euro amount of public procurement in the EU and its share in GDP, published by the European Commission [31, 32], could be found. The data for the years 2004-2011 is available for the 25 EU Member States, but for Bulgaria and Romania for the years 2007-2011, while for Croatia these reports contain no data. The data for Croatia was thus calculated based on the figures listed in the public procurement annual reports of the Croatian Ministry of Economy [33] divided by GDP [34]. Croatian data is also only available from the year 2007 onwards.

However, there is no way to distinguish the share of innovative procurement as part of the total procurement, which would be an appropriate measure for the researched phenomenon PPI. Therefore, the model uses a combined variable which consists of the share of PP in GDP multiplied by a dummy indicator reflecting a government's inclination to use PP for acquiring innovative goods. The dummy was generated from the results of the World Competitiveness Report [25]. Since this indicator is also a component of the $B S \& I$ index, which is the dependent variable, the authors could not include it directly into the model as a numeric variable. Therefore, the countries with results below 4.5 were given the value of the dummy variable $D P P I=0$ and the ones with results above the threshold value were given a $D P P I=1$. This way, the authors created a variable to distinguish between more and less innovative public procurement: $P P \times D P P I=P P I d$. The (un)availability of data for Bulgaria, Romania and Croatia for some of the years in the observed period resulted in an unbalanced panel.

The econometric model therefore includes two variables instead of one for monitoring the PPI:

$$
P P I_{i t}=\beta_{5} P P g d p_{i t}+\beta_{6} P P I d_{i t}
$$

By including (2) in the basic model (1), it becomes the following:

$$
B S \& I_{i t}=\beta_{1}+\beta_{2} \operatorname{COOP}_{i t}+\beta_{3} R Q_{i t}+\beta_{4} G B E R D_{i t}+\beta_{5} P P g d p_{i t}+\beta_{6} P P I d_{i t}+u_{i t}
$$


In addition, the level of innovativeness of the country can also be affected by other factors, which were included in extended models as control variables. These were the following: $G D P$ per capita $(G D P p c), G D P$ growth rate $(G D P g r)$, gross expenditures on R\&D as a percentage of GDP (GERD), government financing share in GERD (GGERD), share of researchers in high-technology and knowledge-intensive activities in the economy (RESemp), export of high-technology products (HTPxp) and the export of knowledge-intensive services $\left(K I S \_x p\right)$. The goal was to find out which among them significantly affected the dependent variable. The data that was previously confirmed to be strongly correlated was not included in the same model to avoid multicollinearity, which is the usual procedure in panel analysis.

Moreover, the literature suggests that the effects of some innovation policy measures may only be seen after a period of time and not immediately [35]. Considering this, the econometric models also tested the effects of the one-year time lag. A two-year time lag showed no consistently significant coefficients in most of the seven tested models. Due to the short time-series data availability, the models could not be tested by longer time lags. The list of the equations for all the tested models is given in the Appendix at the end of the article.

\subsection{Estimates of the econometric panel analysis}

For all the models we tested, the empirical $F$-test suggested that the panel analysis was more appropriate than ordinary regression, i. e. the fixed effects model (FEM) and the random effects model (REM) were more appropriate than the pooled OLS model. The Hausman test confirmed that it was more appropriate to use FEM estimations in all our models and not the REM estimations, which was already expected based on the nature of the used data.

In the next step the tests for heteroskedasticity and/or autocorrelation in the residuals were applied. Heteroskedasticity does not result in unbiased regression coefficients, but standard errors become invalid [36]. A modified Wald statistic for heteroskedasticity in the panel data was used, with Baum's modification, which allows for testing in unbalanced panel data [37]. The Wooldridge test checks if there is autocorrelation between the residuals in successive periods [38]. In all the estimated models, both heteroskedasticity and autocorrelation were found to be present. Then the authors used the procedure recommended by Wooldridge [39] to estimate robust regression coefficients, which account for heteroskedasticity and autocorrelation in the data. These robust coefficients allow the authors to make valid conclusions because they have already taken into consideration the effects that heteroskedasticity and autocorrelation have on the data.

Table I shows the regression coefficients of our estimates based on the original data.

The two variables tend to show significant regression coefficients consistently throughout all the tested models. These are the variable for innovative public procurement (PPId) and GDP growth (GDPgr), wherein the coefficients of PPId are more significant (at $0.1 \%$ ). Based on the calculations in all of the models, it can be assumed that an increase of PPId by one percentage point is connected with an increase in the $B S \& I$ index of about 0.008 (which is the approximate value of the beta estimator in all the tested models). The share of public procurement in the GDP (PPgdp) is only significant for the $B S \& I$ index in the first model.

In Table I, it can also be seen that among other variables the GDP growth rate has significant regression coefficients in all the models at a $1 \%$ level of significance. This indicator represents the economic environment in which businesses operate (whether it is a time of economic expansion or recession). As it follows from the results of the analysis, innovations are usually responsive to deteriorating business conditions such as they become in recession. In the developed models, the regression estimator for GDP growth is not high, but shows that in the observed period in EU countries, higher GDP growth was associated with a higher $B S \& I$ index. 
Table I: Panel analysis of the models with original data.

\begin{tabular}{|llllllll|}
\hline BS\&I & Model 1 & Model 2 & Model 3 & Model 4 & Model 5 & Model 6 & Model 7 \\
\hline COOP & -0.0012 & -0.0009 & -0.0007 & -0.0005 & -0.0014 & -0.0008 & -0.0012 \\
RQ & 0.0270 & 0.1046 & 0.1191 & & & & \\
GBERD & 0.0038 & 0.0019 & 0.0023 & 0.0008 & 0.0013 & 0.0030 & 0.0027 \\
PPgdp & $-0.0198^{* *}$ & -0.0069 & -0.0057 & -0.0040 & -0.0075 & -0.0018 & 0.0004 \\
PPId & $0.0079^{* * *}$ & $0.0084^{* * *}$ & $0.0079^{* * *}$ & $0.0078^{* * *}$ & $0.0080^{* * *}$ & $0.0075^{* * *}$ & $0.0075^{* *}$ \\
GDPgr & & $0.0091^{* *}$ & $0.0092^{* *}$ & $0.0093^{* *}$ & $0.0092^{* *}$ & $0.0081^{* *}$ & $0.0089^{* *}$ \\
HTPxp & & & 0.0019 & 0.0022 & & & 0.0008 \\
KISxp & & & 0.0022 & 0.0025 & & & 0.0024 \\
GGERD & & & & 0.0043 & & & \\
GDPpc & & & & & -0.0000 & & \\
GERD & & & & & & -0.1362 & \\
RESemp & & & & & & \\
Const & $4.6726^{* * *}$ & $4.3357^{* * *}$ & $4.1809^{* * *}$ & $4.1175^{* * *}$ & $4.6875^{* * *}$ & $4.5720^{* * *}$ & -0.2923 \\
\hline R-sqr & 0.1536 & 0.279 & 0.274 & 0.282 & 0.278 & 0.295 & 0.294 \\
$N$ & 155 & 155 & 153 & 152 & 155 & 155 & 151 \\
\hline
\end{tabular}

Notes: ${ }^{*} p<0.05,{ }^{* *} p<0.01,{ }^{* * *} p<0.001$

Source: authors' display from Stata software

The next two tables (II and III) show the results of the modifications of the data and the models that were used to check for the robustness of the presented conclusions. Table II shows the results of the models in which all the values were transformed into their natural logarithmic form and then included into the panel analysis. This enables us to interpret the results a bit differently, in percentage change of the dependent variable based on the percentage change of the explanatory variable.

Table II: Panel analysis of the models with natural logarithm data.

\begin{tabular}{|llllllll|}
\hline InBS\&I & Model 1a & Model 2a & Model 3a & Model 4a & Model 5a & Model 6a & Model 7a \\
\hline $\ln C O O P$ & -0.0083 & -0.0038 & -0.0020 & 0.0047 & -0.0082 & -0.0024 & -0.0066 \\
$\ln R Q$ & -0.0353 & -0.0016 & 0.0042 & & & & \\
$\ln G B E R D$ & -0.0003 & -0.0015 & -0.0006 & -0.0030 & -0.0037 & -0.0006 & 0.0022 \\
$\ln P$ Pgdp & -0.0705 & -0.0175 & -0.0174 & -0.0068 & $-0.0152^{* *}$ & -0.0008 & 0.0103 \\
$\ln P P I d$ & $0.1588^{* * *}$ & $0.1729^{* * *}$ & $0.1654^{* * *}$ & $0.1621^{* * *}$ & $0.1669^{* * *}$ & $0.1660^{* * *}$ & $0.1572^{* *}$ \\
$\ln$ GDPgr & & $0.2266^{* *}$ & $0.2353^{* * *}$ & $0.2535^{* *}$ & $0.2439^{* *}$ & $0.2228^{* *}$ & $0.2210^{* *}$ \\
$\ln H T P x p$ & & & -0.0051 & 0.0000 & & & -0.0098 \\
$\ln$ ISxp & & & 0.0225 & 0.0353 & & & 0.0308 \\
$\ln G G E R D$ & & & & 0.0649 & & & \\
$\ln$ GDPpc & & & & & -0.0626 & & \\
$\ln$ GERD & & & & & & -0.0342 & \\
$\ln R E S e m p$ & & & & & & & -0.0606 \\
Const & $1.6932^{* * *}$ & $1.5184^{* * *}$ & $1.4438^{* * *}$ & $1.1025^{* *}$ & $2.1636^{* *}$ & $1.4716^{* * *}$ & $1.3264^{* * *}$ \\
\hline$R$-sqr & 0.103 & 0.238 & 0.238 & 0.272 & 0.248 & 0.252 & 0.280 \\
$N$ & 155 & 155 & 153 & 152 & 155 & 155 & 151 \\
\hline
\end{tabular}

Notes: ${ }^{*} p<0.05,{ }^{* *} p<0.01,{ }^{* * *} p<0.001$

Source: authors' display from Stata software

The results are pretty similar to the ones obtained by the first version of the regression models. It can be noted that, again, the same two variables consistently show significant regression coefficients, while the other variables are not significant in the tested models. 
Coefficients of the PPId are again more significant (at the $0.1 \%$ level) compared to the significance level of GDPgr coefficients (at the $1 \%$ level).

Table III presents models where the regression model used lagged explanatory variables to determine their impact on the dependent variable, which implies that their past values could affect the values of the dependent variable in the present. As previously mentioned, the policy measures might sometimes produce effects after a medium or long term period of time [35]. The coefficients show mixed levels of significance in these cases and we cannot say they are as robust as in the first two versions of the regression models.

Table III: Panel analysis of the models with one-year time-lag.

\begin{tabular}{|c|c|c|c|c|c|c|c|}
\hline BS\&I & Model 1b & Model 2b & Model 3b & Model 4b & Model 5b & Model 6b & Model 7b \\
\hline L.COOP & -0.0025 & -0.0029 & -0.0029 & -0.0022 & $-0.0045^{* *}$ & -0.0023 & -0.0023 \\
\hline$L . R Q$ & -0.2480 & -0.2650 & -0.2794 & & & & \\
\hline L.GBERD & 0.0071 & 0.0056 & 0.0059 & 0.0050 & 0.0018 & 0.0065 & 0.0064 \\
\hline L.PPgdp & -0.0094 & -0.0027 & -0.0028 & -0.0001 & -0.0015 & 0.0036 & 0.0043 \\
\hline L.PPId & $0.0030^{* * *}$ & $0.0043^{*}$ & 0.0038 & 0.0040 & 0.0026 & 0.0038 & 0.0037 \\
\hline L.GDPgr & & 0.0029 & 0.0029 & 0.0040 & $0.0065^{*}$ & 0.0032 & 0.0036 \\
\hline L.HTPхр & & & -0.0019 & -0.0009 & & & -0.0017 \\
\hline L.KISxp & & & 0.0002 & 0.0012 & & & 0.0013 \\
\hline L.GGERD & & & & 0.0021 & & & \\
\hline L.GDPpc & & & & & $-0.0000^{* * *}$ & & \\
\hline L.GERD & & & & & & -0.1189 & \\
\hline L.RESemp & & & & & & & -0.3142 \\
\hline Const & $4.8693^{* * *}$ & $4.7776^{* * *}$ & $4.8109^{* * *}$ & $4.2634^{* * *}$ & $5.6751^{* * *}$ & $4.4829^{* * *}$ & $4.4716^{* * *}$ \\
\hline$R-s q r$ & 0.1096 & 0.145 & 0.145 & 0.101 & 0.286 & 0.120 & 0.133 \\
\hline$N$ & 155 & 155 & 153 & 152 & 155 & 155 & 151 \\
\hline
\end{tabular}

Source: authors' display from Stata software

These estimates enable the researchers to extract the significant variables for the simulation experiment. The simulations will include PPId and GDPgr as the only explanatory variables in the simulation equations. When considering the results of the versions of the models with logarithmic data and lagged explanatory variables, only logarithmic versions will be simulated due to the insignificance of the regression coefficients for the time-lagged explanatory variables.

\section{SIMULATION MODELS}

Models represent description of a real system which is in fact an abstraction of that system [40] with a purpose to show how this system reacts to a certain change in its environment, i.e. surrounding conditions [41]. Observing the real system helps us to establish relations between the elements of the system (from inputs to outputs) and to quantify them. Modelling is a process that requires going back and forth (from assumption to its confirmation based on reality) in the quest of determining the right model [41]. Simulation then helps us to see how a model will work in certain circumstances but as Pritsker notes [40], there are no basic principles of simulation modelling that would be set and published, such as there are is in some other techniques (e.g. regression assumptions). In the field of policy analysis the best way is to use abductive simulation models that help us to understand how a certain policy impacts an economy and thus offer us arguments for choice of particular policy instruments [15].

Since in the simulation model there should be no variables that are not significant, the simulation in this paper included models with only two explanatory variables. After panel 
analysis shown in previous chapter, we run additional panel analysis with only two explanatory variables in each regression, that have previously shown consistently significant regression coefficients (PPId and GDPgr) and this panel analysis estimations provided the coefficients for the following models:

$$
\begin{gathered}
B S \& I_{i t}=\beta_{1}+\beta_{2} P P I d_{i t}+\beta_{3} G_{D P g r}+u_{i t} \\
\ln \left(B S \& I_{i t}\right)=\ln \beta_{1}+\beta_{2} \ln \left(P P I d_{i t}\right)+\beta_{3} \ln \left(G D P g r_{i t}\right)+u_{i t}
\end{gathered}
$$

The actual simulation equations were as follows:

$$
\begin{gathered}
B S \& I=4.324478+0.00677 \text { PPId }+0.011026 \text { GDPgr } \\
B S \& I=1.45080 * P P I d^{0.14389} * G D P g r^{0.27192}
\end{gathered}
$$

Additionally, since PPId is theoretically bound to the PPgdp as shown in Eq. (2), besides including just PPId in the equation, a new variable was created for the purpose of simulation modelling. It linearly combined (summed) PPgdp and PPId. Therefore, we additionally ran a panel analysis for the following models:

$$
\begin{gathered}
B S \& I_{i t}=\beta_{1}+\beta_{2}(P P g d p+P P I d)_{i t}+\beta_{3} G D P g r_{i t}+u_{i t} \\
\ln \left(B S \& I_{i t}\right)=\ln \beta_{1}+\beta_{2} \ln (P P g d p+P P I d)_{i t}+\beta_{3} \ln \left(G D P g r_{i t}\right)+u_{i t}
\end{gathered}
$$

The results show that both explanatory variables are still significant - GDPgr at $0.1 \%$ and $P P+P P I d$ at $1 \%$ level in model from Eq. (8) and at $5 \%$ level in model from Eq. (9). The resulting simulation equations were as follows:

$$
\begin{gathered}
B S \& I=4.20676+0.00656(P P g d p+P P I d)+0.011837 \text { GDPgr } \\
B S \& I=1.368378 *(P P g d p+P P I d)^{0.02892} * G D P g r^{0.28847}
\end{gathered}
$$

\subsection{Results of the simulations}

Due to the simplicity of tested models the MS Excel application was used for simulation since it can also graphically present the results of the simulations. The graphic results of the simulations, done by Eqs. (6), (7), (10) and (11), can be seen below. In simulations based on Eqs. (6) and (10) the variable GDPgr was set in range [-2.5\%; $5 \%$ in line with the expectations of the possible economic growth of EU economies in the following period. This variable is external in the sense that a government cannot directly determine GDP growth. Variable Public procurement for innovation is taken into simulation in range $[7.5 \% ; 30.5 \%$ ] because these are the real values of public procurement in GDP of EU countries. Thus, the simulation shows what would be the effect on the value of $B S \& I$ index if all this public procurement would be innovation-oriented. In the case of combined variable PPgdp+PPId the range is the same, $[7.5 \% ; 30.5 \%$, even though this variable takes double value of public procurement in cases when the dummy for PPI is 1 (the governments of these countries were evaluated as being innovation-oriented in public procurement). Until now, the maximum value of innovative public procurement has been $20.30 \%$ of GDP, but the positive effect on the innovativeness level would suggest increasing the innovative public procurement. Figs. 2 and 3 show the results of the simulation. 


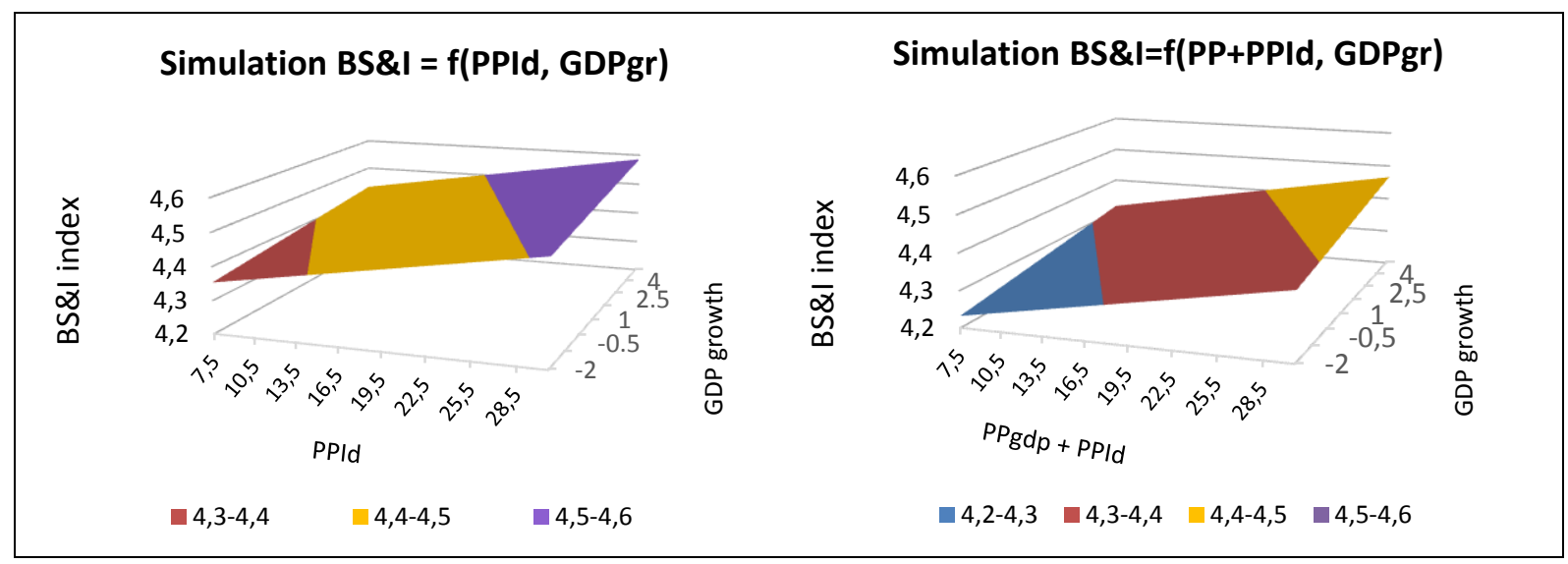

Figure 2: Results of the simulation models based on the original data estimations.

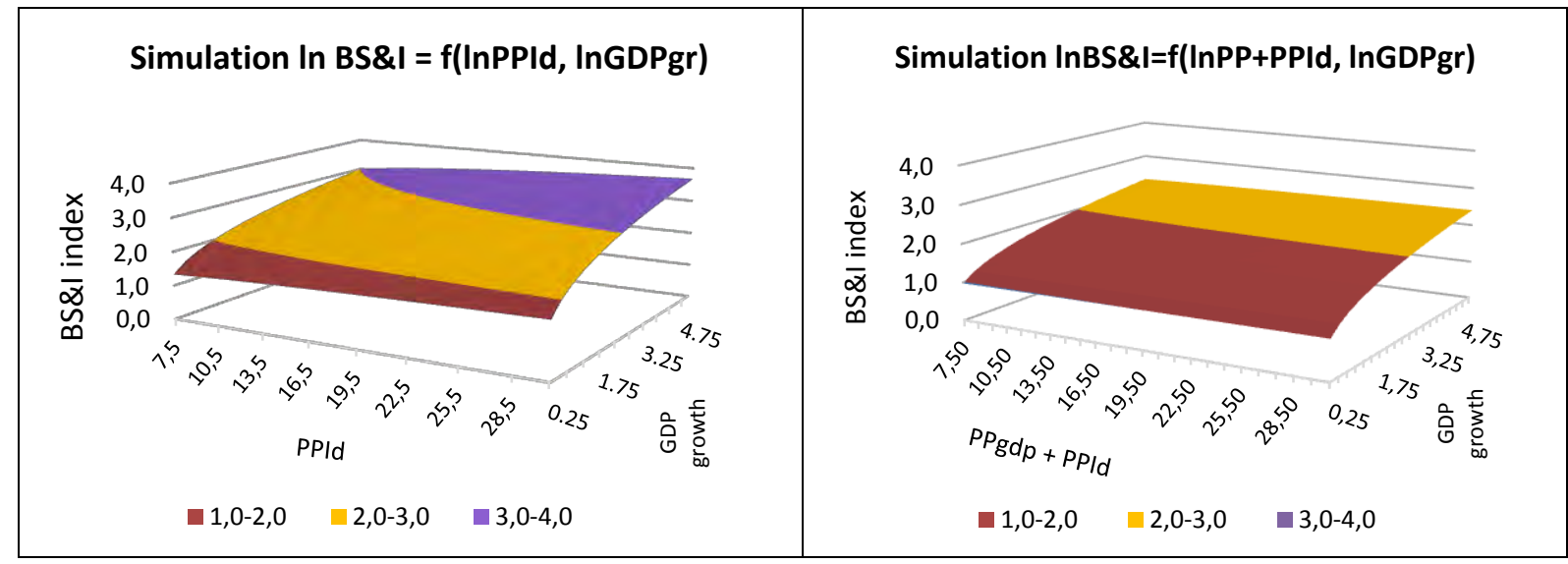

Figure 3: Results of the simulation models based on the logarithmic data estimations.

\subsection{Discussion}

As we can see in Fig. 2, the results of the simulations with original variables, with PPId, $P P+P P I d$ and GDPgr as explanatory variables, show a number of possible results for $B S \& I$ with stronger effect of the PPId and $P P+P P I d$ on the increase of the level of innovativeness of the country. Since policymakers cannot directly determine GDP growth, possible yearly growth rates are expected to be in the range we set. Increasing public procurement for innovation can raise the innovativeness level by more than 0.2 points, thus raising the overall competitiveness of the country. In cases where the logarithmic transformation of the variables was applied (Fig. 3), the area of $B S \& I$ results is not determined in the set of real numbers for the values of GDPgr below zero, due to the characteristics of the logarithmic function. The results are somewhat different, where we can see that adding $P P$ into the equation lessens the effect of public procurement on innovation. This is in line with the expectations based on the previous panel analysis, where public procurement had a negative impact on the level of innovativeness as can be seen in Models 1, 1a and $1 \mathrm{~b}$ (Tables I, II and III) whereas in Model 1 this impact is even significant at the level of $1 \%$.

Of course, innovative public procurement is not the only variable that affects the innovativeness level of a country since the tested models explain only $24-30 \%$ of the change in the level of innovativeness (measured by the determination coefficient $R$-squared). As is often the case in research, the authors of this study also faced the restrictions and limitations. These mainly stem from the fact that EU countries do not systematically monitor the appropriate indicators for the exploration of the chosen phenomenon. Some indicators are new and for others, the surveillance methods vary over time, so despite the existence of a long 
time series, a comparison of some indicators across different time periods is not possible. This results in a relatively short time series that is appropriate for the analysis. That is why for some variables the chosen indicators are only approximations of the observed phenomena, and some variables were omitted, since in the observed period the method of monitoring has been changed.

This proved to be the main limitation of this study, because some results were insignificant, and a more complex dynamic panel analysis could not even be performed. However, we believe that the survey confirmed the relevance of the impact of public procurement on promoting innovation, which is also in line with the results of other, mainly qualitative studies, on this topic.

\section{CONCLUSION}

Public procurement for innovation (PPI) is one of the policy measures in focus of the innovation policy in recent years, since the EU set the promotion of innovation highly in its strategy until 2020. In the past, in practice there was a great emphasis on the development of the stimulus for innovation on the supply side (e.g. subsidies for research and development), but in recent years more and more attention is focused on the demand side, where PPI emerges as an increasingly important instrument of innovation policies.

The results of research at the level of the EU countries shows that in all versions of the models that analysed the impact of various instruments of innovation policy on innovation, PPI was revealed to be an influential factor. In the extended models, the rate of economic growth has also become an important factor. Based on the panel's analysis, the simulation model was built, which was to highlight the potential impact of the innovation-oriented public procurement on the level of a country's innovativeness. Results show significant impact of the PPI on the innovativeness, but the problem still remains collection of the data that measure this kind of public procurement. Recent changes in the Community Innovation Survey (CIS) show determination of the EU to cope with this issue [27], since in the last version of the questionnaire they added question about the customers who induced reported innovations, whether they origin from private or from public sector. This looks promising for the future research since more detailed data will be available and enable better analyses. Despite the previously mentioned limitations in the study of the researched phenomenon, the simulation model analysis shows interesting results and provides additional arguments for evidencebased innovation policies.

\section{REFERENCES}

[1] Edquist, C.; Hommen, L. (2000). Public technology procurement and innovation theory, Edquist, C.; Hommen, L.; Tsipouri, L. J. (Eds.), Public technology procurement and innovation, Springer, New York, 5-70

[2] Edler, J.; Edquist, C.; Georghiou, L.; Hommen, L.; Hafner, S.; Papadakou, M.; Rigby, J; Rolfstam, M.; Ruhland, S.; Tsipouri, L. (2005). Innovation and public procurement. Review of issues at stake, Fraunhofer Institute for Systems and Innovation Research, from http://cordis.europa.eu/innovation-policy/studies/full_study.pdf, accessed on 09-08-2011

[3] Aho, E.; Cornu, J.; Georghiou, L.; Subira, A. (2006). Creating an Innovative Europe (Report of the Independent Expert Group on R\&D and Innovation), from http://ec.europa.eu/invest-inresearch/pdf/download_en/aho_report.pdf, accessed on 15-09-2011

[4] Edler, J.; Georghiou, L. (2007). Public procurement and innovation - Resurrecting the demand side, Research Policy, Vol. 36, No. 7, 949-963, doi:10.1016/j.respol.2007.03.003

[5] Detelj, K. (2015). Public procurement as a tool for promotion of innovations (PhD), University of Maribor, Faculty of Economics and Business, Maribor 
[6] Aschhoff, B.; Sofka, W. (2009). Innovation on demand - Can public procurement drive market success of innovations?, Research Policy, Vol. 38, No. 8, 1235-1247, doi:10.1016/ j.respol.2009.06.011

[7] Guerzoni, M.; Raiteri, E. (2012). Innovative public procurement and R\&D Subsidies: hidden treatment and new empirical evidence on the technology policy mix in a quasi-experimental setting (No. 18/2012) (p. 32), Torino: Dipartimento di Economia "S. Cognetti de Martiis.", from http://brick.carloalberto.org/images/publications/18_wp_2012.pdf, accessed on 15-04-2013

[8] Detelj, K.; Jagric, T.; Markovic-Hribernik, T. (2016). Exploration of the effectiveness of public procurement for innovation: Panel analysis of EU countries' data, Lex Localis - Journal of Local Self-Government, Vol. 14, No. 1, 93-114, doi:10.4335/14.1.93-114(2016)

[9] Buchmeister, B.; Friscic, D.; Palcic, I. (2014). Bullwhip effect study in a constrained supply chain, Procedia Engineering, Vol. 69, 63-71 doi:10.1016/j.proeng.2014.02.204

[10] Kremljak, Z.; Palcic, I.; Kafol, C. (2014). Project evaluation using cost-time investment simulation, International Journal of Simulation Modelling, Vol. 13, No. 4, 447-457, doi:10.2507/IJSIMM13(4)5.279

[11] Dawid, H.; Gemkow, S.; Harting, P.; van der Hoog, S.; Neugart, M. (2014). Agent-based macroeconomic modeling and policy analysis: the Eurace@Unibi model, from http://papers.ssrn.com/sol3/papers.cfm?abstract_id=2384391, accessed on 16-08-2015

[12] Bauman, M.; Lobnik, A.; Hribernik, A. (2011). Decolorization and modeling of synthetic wastewater using $\mathrm{O}_{3}$ and $\mathrm{H}_{2} \mathrm{O}_{2} / \mathrm{O}_{3}$ processes, Ozone: Science \& Engineering, Vol. 33, No. 1, 23 30, doi: $10.1080 / 01919512.2011 .536448$

[13] Ouliaris, S. (2012). Economic models: simulations of reality, IMF Finance \& Development, from http://www.imf.org/external/pubs/ft/fandd/basics/models.htm, accessed on 31-03-2015

[14] Van Dinther, C. (2008). Agent-based simulation for research in economics, Seese, D.; Weinhardt, C.; Schlottmann, F. (Eds.), Handbook on information technology in finance, Springer, Berlin, 421-442

[15] Brenner, T.; Werker, C. (2009). Policy advice derived from simulation models, Journal of Artificial Societies and Social Simulation, Vol. 12, No. 4, from http://jasss.soc.surrey.ac.uk/ 12/4/2.html, accessed on 20-03-2015

[16] Leber, M.; Bastic, M.; Buchmeister, B. (2014). The trends in usage and barriers of innovation management techniques in new product development, Strojniski vestnik - Journal of Mechanical Engineering, Vol. 60, No. 6, 382-388, doi:10.5545/sv-jme.2013.1611

[17] Palcic, I.; Buchmeister, B.; Polajnar, A. (2010). Analysis of innovation concepts in Slovenian manufacturing companies, Strojniski vestnik - Journal of Mechanical Engineering, Vol. 56, No. $12,803-810$

[18] Koren, R.; Palcic, I. (2015). The impact of technical and organisational innovation concepts on product characteristics, Advances in Production Engineering \& Management, Vol. 10, No. 1, 27 39, doi:10.14743/apem2015.1.190

[19] Mazzucato, M.; Perez, C. (2015). Innovation as growth policy: the challenge for Europe, Fagerberg, J.; Laestadius, S.; Martin, B. R. (Eds.), The Triple Challenge for Europe: Economic Development, Climate Change, and Governance, Oxford University Press, Oxford, 227-262

[20] Veugelers, R.; Schweiger, H. (2015). Innovation policies in transition countries: one size fits all?, Economic Change and Restructuring, 27 pages, doi:10.1007/s10644-015-9167-5

[21] Gebhardt, C.; Stanovnik, P. (2016). European innovation policy concepts and the governance of innovation: Slovenia and the struggle for organizational readiness at the national level, Industry and Higher Education, Vol. 30, No. 1, 53-66, doi:10.5367/ihe.2016.0290

[22] Rolfstam, M. (2009). Public procurement as an innovation policy tool: the role of institutions, Science and Public Policy, Vol. 36, No. 5, 349-360, doi:10.3152/030234209X442025

[23] Baltagi, B. H. (2005). Econometric Analysis of Panel Data ( ${ }^{\text {rd }}$ ed.), John Wiley \& Sons Ltd., West Sussex

[24] Basarac, M.; Škrabić, B.; Sorić, P. (2011). The hybrid Phillips curve: Empirical evidence from transition economies, Czech Journal of Economics and Finance, Vol. 61, No. 4, 367-383

[25] WEF (2014). The global competitiveness report 2014-15, World Economic Forum, from http://www3.weforum.org/docs/WEF_GlobalCompetitivenessReport_2014-15.pdf, accessed on 10-03-2015 
[26] Sala-i-Martin, X.; Bilbao-Osorio, B.; Blanke, J.; Hanouz, M. D.; Geiger, T. (2011). The global competitiveness index 2011-2012, Part 1: Measuring competitiveness, The global competitiveness index 2011-2012, Schwab, K. (Ed.), The Global Competitiveness Report 20112012, 3-49, World Economic Forum, Geneva, from www3.weforum.org/docs/WEF_GCR_ Report_2011-12.pdf, accessed on 06-08-2012

[27] Eurostat (n.d.). European statistics, European Commission - Eurostat, Portal with European statistical data, from http://epp.eurostat.ec.europa.eu/portal/page/portal/eurostat/home/, accessed on 22-08-2013

[28] WGI project (2012). Worldwide governance indicators, The World Bank Group, from http://info.worldbank.org/governance/wgi/index.asp, accessed on 02-09-2013

[29] EU (2015). Public procurement in EU - Rules \& procedures, Your Europe portal, from http://europa.eu/youreurope/business/public-tenders/rules-procedures/index_en.htm, accessed on 16-11-2015

[30] Kapff, L. (2013). Quantifying public procurement of R\&D in Europe, from http://www.frp.nrw.delfrp2/_dld/va/v777/802_PCP\%20and\%20PPI\%20Berlin\%20event\%202122\%20March-2013_LK.pdf, accessed on 20-07-2013

[31] EC (2010). Public procurement indicators 2008, European Commission, Brussels, from http://ec.europa.eu/internal_market/publicprocurement/docs/indicators2008_en.pdf, accessed on 25-08-2013

[32] EC (2012). Public procurement indicators 2011, European Commission, Brussels, 11 pages, from http://ec.europa.eu/internal_market/publicprocurement/docs/modernising_rules/publicprocurement-indicators-201̄_en.pdf, accessed on 25-08-2013

[33] MINGORP (2009). Javna nabava, Minivodič za poslovnu zajednicu, Ministarstvo gospodarstva, rada i poduzetništva, Project BIZimpact, EU CARDS project: EuropeAid/121473/C/SV/HR, 28 pages, from www.javnanabava.hr/userdocsimages/userfiles/file/Razne\%20publikacije/ Minivodic_za_poslovnu_zajednicu.pdf, accessed on 27-08-2013

[34] Worldbank (n.d.) Worldbank data, from http://data.worldbank.org/indicator, accessed on 22-082013

[35] Edler, J., Georghiou, L., Blind, K., Uyarra, E. (2012). Evaluating the demand side: New challenges for evaluation. Research Evaluation, Vol. 21, No. 1, 33-47, doi:10.1093/ reseval/rvr002

[36] Wooldridge, J. (2002). Introductory econometrics: A Modern Approach (2 ${ }^{\text {nd }}$ ed.), South-Western College Pub, Mason

[37] Baum, C. F. (2013). Modified Wald statistic for groupwise heteroskedasticity in fixed effect model, help file in STATA program (Boston Colege Department of Economics), Boston

[38] Drukker, D. M. (2003). Testing for serial correlation in linear panel-data models, The Stata Journal, Vol. 3, No. 2, 168-177

[39] Wooldridge, J. M. (2011). st: RE: testing heteroksedasticity and autocorrelation fixed effect model, Stata Data Analysis and Statistical Software, from http://www.stata.com/statalist/ archive/2011-03/msg00091.html, accessed on 15-12-2013

[40] Pritsker, A. A. B. (1998). Principles of simulation modeling, Banks, J. (Ed.), Handbook of Simulation: Principles, Methodology, Advances, Applications, and Practice, Wiley, New York, 31-51

[41] Sánchez, P. J. (2007). Fundamentals of simulation modeling, Proceedings of the 2007 Winter Simulation Conference, IEEE Press, 54-62 


\section{Appendix A}

\begin{tabular}{|c|c|}
\hline & Models with original variables \\
\hline 1 & $B S \& I_{i t}=\beta_{1}+\beta_{2} \operatorname{COOP}_{i t}+\beta_{3} R Q_{i t}+\beta_{4} G B E R D_{i t}+\beta_{5} P P_{i t}+\beta_{6} P P I d_{i t}+u_{i t}$ \\
\hline 2 & $B S \& I_{i t}=\beta_{1}+\beta_{2} \operatorname{COOP}_{i t}+\beta_{3} R Q_{i t}+\beta_{4} G B E R D_{i t}+\beta_{5} P P_{i t}+\beta_{6} P P I d_{i t}+\beta_{7} G D P g r_{i t}+u_{i t}$ \\
\hline 3 & $B S \& I_{i t}=\beta_{1}+\beta_{2} \operatorname{COOP}_{i t}+\beta_{3} R Q_{i t}+\beta_{4} G B E R D_{i t}+\beta_{5} P P_{i t}+\beta_{6} P_{P I d_{i t}}+\beta_{7} G D P g r_{i t}+\beta_{8} H T P x p_{i t}+\beta_{9} K I S x p_{i t}+u_{i t}$ \\
\hline 4 & $B S \& I_{i t}=\beta_{1}+\beta_{2} \operatorname{COOP}_{i t}+\beta_{4} G B E R D_{i t}+\beta_{5} P P_{i t}+\beta_{6} P_{P I d}+\beta_{7} G D P \_g r_{i t}+\beta_{8} H_{T P x} p_{i t}+\beta_{9} K_{I S x p}+\beta_{10} G G E R D_{i t}+u_{i t}$ \\
\hline 5 & $B S \& I_{i t}=\beta_{1}+\beta_{2} \operatorname{COOP}_{i t}+\beta_{4} G B E R D_{i t}+\beta_{5} P P_{i t}+\beta_{6} P P I d_{i t}+\beta_{7} G D P g r_{i t}+\beta_{11} G D P_{-} p c_{i t}+u_{i t}$ \\
\hline 6 & $B S \& I_{i t}=\beta_{1}+\beta_{2} \operatorname{COOP}_{i t}+\beta_{4} G B E R D_{i t}+\beta_{5} P P_{i t}+\beta_{6} P_{P I d}+\beta_{7} G D P g r_{i t}+\beta_{12} G E R D_{i t}+u_{i t}$ \\
\hline \multirow[t]{2}{*}{7} & $B S \& I_{i t}=\beta_{1}+\beta_{2} \operatorname{COOP}_{i t}+\beta_{4} G B E R D_{i t}+\beta_{5} P P_{i t}+\beta_{6} P_{P I d}+\beta_{7} G_{i t} P g r_{i t}+\beta_{8} H_{T P x p}+\beta_{9} K_{I S x p}+\beta_{13} R_{i t} \operatorname{Semp}_{i t}+u_{i t}$ \\
\hline & Models with logarithmic variables \\
\hline 1a & $\ln . B S \& I_{i t}=\ln . \beta_{1}+\beta_{2} \ln . \operatorname{COOP}_{i t}+\beta_{3} \ln . R Q_{i t}+\beta_{4} \ln . G B E R D_{i t}+\beta_{5} \ln . P P_{i t}+\beta_{6} \ln . P P I d_{i t}+u_{i t}$ \\
\hline $2 \mathrm{a}$ & $\ln . B S \& I_{i t}=\ln . \beta_{1}+\beta_{2} \ln . C O O P_{i t}+\beta_{3} \ln . R Q_{i t}+\beta_{4} \ln . G B E R D_{i t}+\beta_{5} \ln . P P_{i t}+\beta_{6} \ln . P P I d_{i t}+\beta_{7} \ln . G D P g r_{i t}+u_{i t}$ \\
\hline $3 \mathrm{a}$ & $\begin{aligned} \ln . B S \& I_{i t}=\ln . \beta_{1}+ & \beta_{2} \ln . \operatorname{COOP}_{i t}+\beta_{3} \ln . R Q_{i t}+\beta_{4} \ln . G B E R D_{i t}+\beta_{5} \ln . P P_{i t}+\beta_{6} \ln . P P I d_{i t}+\beta_{7} \ln . G D P g r_{i t}+\beta_{8} \ln . H T P x p_{i t} \\
& +\beta_{9} \ln . K I S x p_{i t}+u_{i t}\end{aligned}$ \\
\hline $4 \mathrm{a}$ & $\begin{aligned} \ln . B S \& I_{i t}=\ln . \beta_{1} & +\beta_{2} \ln \cdot C O O P_{i t}+\beta_{4} \ln . G B E R D_{i t}+\beta_{5} \ln . P P_{i t}+\beta_{6} \ln . P P I d_{i t}+\beta_{7} \ln . G D P g r_{i t}+\beta_{8} \ln . H T P x p_{i t}+\beta_{9} \ln . K_{1} \operatorname{Sxp}_{i t} \\
& +\beta_{10} \ln . G G E R D_{i t}+u_{i t}\end{aligned}$ \\
\hline $5 \mathrm{a}$ & $\ln . B S \& I_{i t}=\ln . \beta_{1}+\beta_{2} \ln \cdot C O O P_{i t}+\beta_{4} \ln . G B E R D_{i t}+\beta_{5} \ln . P P_{-} G D P_{i t}+\beta_{6} \ln . P P I_{-} 2_{i t}+\beta_{7} \ln . G D P g r_{i t}+\beta_{11} \ln . G D P p c_{i t}+u_{i t}$ \\
\hline $6 \mathrm{a}$ & $\ln . B S \& I_{i t}=\ln . \beta_{1}+\beta_{2} \ln \cdot \operatorname{COOP}_{i t}+\beta_{4} \ln \cdot G B E R D_{i t}+\beta_{5} \ln \cdot P P_{i t}+\beta_{6} \ln . P P I d_{i t}+\beta_{7} \ln . G D P g r_{i t}+\beta_{12} \ln . G E R D_{i t}+u_{i t}$ \\
\hline \multirow[t]{2}{*}{$7 \mathrm{a}$} & $\begin{aligned} \ln . B S \& I_{i t}=\ln . \beta_{1}+ & \beta_{2} \ln . C O O O P_{i t}+\beta_{4} \ln . G B E R D_{i t}+\beta_{5} \ln . P P_{i t}+\beta_{6} \ln . P P I_{i t}+\beta_{7} \ln . G D P g r_{i t}+\beta_{8} \ln . H T P x p_{i t}+\beta_{9} \ln . K I S x p_{i t} \\
& +\beta_{13} \ln . R E S e m p_{i t}+u_{i t}\end{aligned}$ \\
\hline & Models with one-year lagged variables \\
\hline $1 \mathrm{~b}$ & $B S \& I_{i t}=\beta_{1}+\beta_{2} l . C O O P_{i t}+\beta_{3} l . R Q_{i t}+\beta_{4} l . G B E R D_{i t}+\beta_{5} l . P P_{i t}+\beta_{6} l . P P I d_{i t}+u_{i t}$ \\
\hline $2 b$ & $B S \& I_{i t}=\beta_{1}+\beta_{2} l . C O O P_{i t}+\beta_{3} l_{.} R Q_{i t}+\beta_{4} l . G B E R D_{i t}+\beta_{5} l . P P_{i t}+\beta_{6} l . P P I d_{i t}+\beta_{7} l . G D P g r_{i t}+u_{i t}$ \\
\hline $3 \mathrm{~b}$ & $\begin{aligned} & B S \& I_{i t}=\beta_{1}+\beta_{2} l . C O O P_{i t}+\beta_{3} l . R Q_{i t}+\beta_{4} l . G B E R D_{i t}+\beta_{5} l . P P_{i t}+\beta_{6} l . P P I d_{i t}+\beta_{7} l . G D P g r_{i t}+\beta_{8} l . H T P x p_{i t}+\beta_{9} l . K I S x p_{i t} \\
&+u_{i t}\end{aligned}$ \\
\hline $4 \mathrm{~b}$ & $\begin{array}{c}B S \& I_{i t}=\beta_{1}+\beta_{2} l . C O O P_{i t}+\beta_{4} l . G B E R D_{i t}+\beta_{5} l . P P_{i t}+\beta_{6} l . P P I d_{i t}+\beta_{7} l . G D P g r_{i t}+\beta_{8} l . H T P x p_{i t}+\beta_{9} l . K I S x p_{i t} \\
+\beta_{10} l_{.} G G E R D_{i t}+u_{i t}\end{array}$ \\
\hline $5 \mathrm{~b}$ & $B S \& I_{i t}=\beta_{1}+\beta_{2} l . C O O P_{i t}+\beta_{4} l . G B E R D_{i t}+\beta_{5} l . P P_{i t}+\beta_{6} l . P P I d_{i t}+\beta_{7} l . G D P g r_{i t}+\beta_{11} l . G D P p c_{i t}+u_{i t}$ \\
\hline $6 \mathrm{~b}$ & $B S \& I_{i t}=\beta_{1}+\beta_{2} l . C O O P_{i t}+\beta_{4} l . G B E R D_{i t}+\beta_{5} l . P P_{i t}+\beta_{6} l . P P I d_{i t}+\beta_{7} l . G D P g r_{i t}+\beta_{12} l . G E R D_{i t}+u_{i t}$ \\
\hline $7 \mathrm{~b}$ & $\begin{array}{c}B S \& I_{i t}=\beta_{1}+\beta_{2} l . C O O P_{i t}+\beta_{4} l . G B E R D_{i t}+\beta_{5} l . P P_{i t}+\beta_{6} l . P P I_{i t}+\beta_{7} l . G D P g r_{i t}+\beta_{8} l . H T P x p_{i t}+\beta_{9} l . K I S x p_{i t} \\
+\beta_{13} l . R E S e m p_{i t}+u_{i t}\end{array}$ \\
\hline
\end{tabular}

